\title{
ОСОБЕННОСТИ КОНЦЕПЦИИ МОНЕТАРИЗМА В РОССИЙСКОЙ ЭКОНОМИКЕ
}

\author{
(c) 2021 Магомадов Эмин Мухадинович \\ кандидат экономических наук, доцент кафедры учета, анализа и аудита в цифровой экономике \\ Чеченский государственный университет, Россия, Грозный
}

(c) 2021 Муртазалиева Амина Хамзатовна

3 курс Института экономики и финансов Чеченский государственный университет, Россия, Грозный

В данной статье проводится анализ монетарного регулирования экономики России. Актуальность исследования обуславливается потребностью понятия методов регулирования экономики. В процессе исследования рассмотрены темпы роста ВВП до и после введения международных санкций, инструменты монетарной политики в России и основная концепция монетаризма. Информационной базой исследования стали официальные публикации в рамках проектного офиса IMB, разработки Агентства стратегических инициатив, Федерального агентства научных организаций, ресурсы сети Интернет и собственные разработки авторов.

Ключевые слова: монетарная политика, ВВП, монетарный климат, денежная система, информационная среда.

Понятия монетарный механизм, монетарная политика, монетарное регулирование очень часто встречаются в современной экономической литературе. Российский экономист Леонид Лопатников рассматривает термин «monetary policy» как «денежную политику».

Сам термин «монетаризм» появился на рубеже шестидесятых годов двадцатого века в учениях швейцарского и американского экономиста Карла Бруннера. В развитии экономики, как считают представители данной школы, главная значимость придается денежным отношениям. В переменности денежных параметров представляется ключевой мотив непостоянности стабильности экономики. Идеи значимости денежной сферы были замечены в работах Джона Стюарта Милля, Давида Юма, Юлия Павла, древнеримских юристов, несмотря на недавнее появление термина «монетарное регулирование» в литературных и научных источниках. В VIII веке была основана школа монетаризма американским экономистом Мильтоном Фридменом. В содержании книги «Теория функции потребления», изданной в 1957-м году, имеются главные теории и принципы школы М.Фридмана. Главным инструментом воздействия на динамику ВНП М.Фридмен определяет денежное обращение в стране. Известными сторонниками монетаризма являются Анна Шварц, Аллан Мелцер, Эдмунд Фелпс, Дэвид Эрнест Лейдлер, Р. Селден, Филлип Кейган.
«Экономическая свобода обуславливает все остальные свободы общества»- формулировал М.Фридмен, отображая современный капитализм. Только невмешательство государства в экономику позволит реализовать идею экономической независимости, а также стабилизировать долю доходов государства, составляющих финансовую платформу экономики. Субъективность неоклассического движения теории Фридмана заключается в том, что психологические факторы в экономике создают ту цепь, по которой элементы экономической системы стремятся к равномерности. Это служит ключевой чертой в данной концепции, т.е. учёт психологического фактора - аргументов действия человека в непредвиденных экономических обстоятельствах. Так как внешние воздействия имеют шансы спровоцировать отклонения от запланированного направления экономики, именно государственное вмешательство в экономику препятствует функционированию естественных регуляторов, содействующих достижению баланса на краткосрочной перспективе. «Денежный импульс» является центральным регулятором, воздействующим на хозяйственную составляющую экономики, и определяет наиболее прочную настройку денежно-кредитной и валютной политик государства. Мильтон Фридмен отмечал, также, наличие корреляционной связи между темпом роста денежных параметров и прогрессом национального дохода, ори- 
ентируясь на статистические данные в области монетарного регулирования экономики в США и других странах.

Приход к власти Рональда Рейгана стал первопричиной стратегического поворота в сторону монетаризма США. Рейган стал реализовывать финансовую программу под названием “рейганомика”, благодаря которой в Соединённых Штатах Америки ввелась категория пониженных темпов роста денежной структуры, что и служило ключевым элементом монетарной политики.

Репутация монетаризма в настоящее время определяется наличием особого внимания стран к общепризнанным национальным стандартам регулирования денежно-кредитной политики. Во многих произведениях современной экономической литературы комментируются основные положения монетарной сферы. В книге Кэмпбелла Макконелля и Стенли Брю «Экономикс» проводится сравнительный анализ теоретических и методологических взглядов кейнсианской и монетаристской теорий. Профессор Цюрихского университета Б.Фримен в 1983 году провел международный опрос, с целью доказать необходимость монетарного регулирования экономики на сегодняшний день, в котором участвовали 931 известных экономистов Германии, Австрии и США.

В 2018 году в Молдавии в связи с кризисным состоянием экономики, основными причинами которого стали резкое сокращение из-за границы денежных переводов, сужение совокупного спроса и внешней торговли, Национальный банк Молдавии отказался от режима таргетирования денежных агрегатов, установив уровень инфляции на конец года 9\%. В республике проводилась политика «дешевых денег»: норма обязательных резервов снижена до 8\%, ставка рефинансирования упала до $5 \%$.

Концепция монетаризма представляет собой устойчивую систему, характеризующуюся состоянием динамического равновесия при оптимальной занятости ресурсов, т.е. способностью рыночной системы самостоятельно достигать макроэкономического равновесия. Последствием нарушения рыночного равновесия является финансово-экономический кризис, который подразумевает следствие вмешательства государства в естественный ход экономической жизни общества, основной причиной которых определяют сдвиги в денежной сфере. В долго- срочном периоде нестабильность денег всегда сопровождается нестабильностью экономического роста. В обществе всегда стабильным показателем рыночного механизма, как утверждает Мильтон Фридмен, является спрос на деньги. А предложение характеризуется нестабильностью и зависит от конкретных решений денежнокредитных институтов. При превышении норм выпускаемой денежной массы растет инфляция. А в случае понижения количества выпускаемых денег над нормами следует финансовый кризис. Таким образом, от монетарного фактора зависит весь ход экономического процесса.

В 1968 и 1972 гг. президент Соединённых Штатов Америки Ричард Никсон впервые применил данную монетаристскую концепцию в экономике. В то время советником президента являлся основоположник монетаризма Мильтон Фридман. Большого успеха в применении данной концепции достигли в Великобритании в 1975 году и в 1972 году в Америке во время реализации программы «рейганомика».

В 1991 году правительство России официально провозгласило приверженность принципам монетаризма и начало использования монетаристской концепции на практике путем создания рычагов регулирования объема предложения денег для стабилизации рыночных отношений. Финансовые институты России проводили государственную монетарную политику, включающую в себя: торговые сделки на рынках со свободным входом и выходом, функции, обеспечивающие равновесие показателей резервных структур, законодательные ограничения в определении постоянных и переменных экономических величин.

При проведении государством одновременно фискальной и монетарной политик, необходимо придерживаться определённых правил, позволяющих обеспечивать равновесие показателей как микроэкономики, так и макроэкономики. Результаты осуществления государственными структурами данной деятельности зависят от рационального распределения и соответствия переменных элементов. Стабилизация постоянных встроенных фискальных режимов требует соблюдение особой упорядоченности инструментов каждой политики (см. табл. 1).

Основным недостатком в современном практическом применении монетарной концепции в экономике страны является то, что нынешняя денежная система характеризуются 
Таблица 1. Меры государства по стабилизации экономики

\begin{tabular}{|l|c|c|}
\hline \multicolumn{1}{|c|}{ Инструменты } & Стимулирующая политика & Сдерживающая политика \\
\hline $\begin{array}{l}\text { Монетарная политика: } \\
\text { - норматив обязательных резервов; } \\
\text { - учетная ставка; } \\
\text { - операции на открытом рынке. }\end{array}$ & Снижение, & Повышение, \\
\hline $\begin{array}{l}\text { Фискальная политика: } \\
\text { - налоги; } \\
\text { государственные расходы. }\end{array}$ & ПокупкацБ ГЦБ \\
\hline
\end{tabular}

Составлено автором на основе статистических данных официального сайта Министерства финансов Российской Федерации. Информационно-аналитический раздел.http://info.minfin.ru

многофакторностью и высокой динамичностью.

Категории осуществления монетарной политики и принципы монетаризма в плане практического применения в науке и в рыночных отношениях пользуются высокой актуальностью в нынешних экономических условиях. Сложность теории денег состоит в нестабильности действий денежных механизмов. Часто наблюдаются ошибки в разработках современных экономистов в концепциях управления денежной системой страны. Существуют два проводника Центрального банка - «банк банков» и «банк правительства». K функциям первого относят: предоставление кредитов коммерческим банкам, регулирование правил и условий деятельности КБ, установление норм и хранение обязательных резервов. «Банк правительства» осуществляет: внешние расчеты, хранение золотовалютных запасов, эмиссию денег, является агентом правительства при обслуживании бюджета.

При финансовом подходе к сущности монетарной политики, ключевой сегмент образуют вопросы о ставках налогов и сборов, уровень и структуру бюджетных расходов, дефицита государственного бюджета и др. Очевидно, это слишком расширенное понятие, которое включает в монетарную политику не только регулирование денежного обращения, но и все отношения, которые на него влияют, даже если они не входят в число денежных, банковских, но управляются центральным банком. Некоторые ученые являются сторонниками широкого подхода, при котором к монетарной политике принадлежит комплекс мероприятий государства в денежной сфере, включая те, которые осуществляются и без участия центрального банка. Встречаются и узкие трактовки монетарной политики, например, как совокупность средств воздействия на предложение денег или на валютные курсы. Американский экономист Фредерик С. Мишкин, также, обосновывает узкое понятие монетарной политики, сводя ее суть к управлению предложением денег и процентными ставками. Однако, с нашей точки зрения, ограничение использования механизма монетарной концепции только воздействием на предложение денег и на процентные ставки, приводит к уменьшению результативных возможностей государства на увеличение состояния денежной сферы. Можно считать, что монетарное регулирование является более широким понятием, которое охватывает не только денежно-кредитную политику и механизм ее реализации, но и еще такую важную сферу государственного регулирования экономических процессов, которая отражает уже особенности организации валютных отношений и реализуются через механизм разработки и практической реализации валютной политики, а также конкретных сфер ее практического производства. С недавних пор, важным инструментом монетарного регулирования служит индекс монетарной эффективности (ИМЭ), с помощью которого отдельно оцениваются стабильность монетарной системы и предпринимательская свобода финансовых агентов.

Российский мегарегулятор системно придерживается идеологии ужесточения наказания в ущерб построению системы поощрений, тем самым перенося внешние санкции на «плохих» участников рынка вместо того, чтобы всячески поддерживать «хорошие» предприятия и банки. По данным Росстата, темп экономического роста за санкционный период в среднем в 6 раз уменьшился по сравнению с периодом до санкций. (см. табл. 2) Учитывая, что каждый пункт прироста ИМЭ дает полтора процента прироста ВВП, можно говорить, что в среднем за санкционный период Банк России своими действиями обеспечил потенциальный годовой рост экономики на 9\%. Вместе с тем очевидно и то, что санкции спровоцировали Банк России на систе- 
Таблица 2. Темпы роста ВВП России до и после введения международных санкций

\begin{tabular}{|c|c|c|c|}
\hline \multicolumn{2}{|c|}{ До санкций } & \multicolumn{2}{c|}{ После санкций } \\
\hline Год & Темп роста ВВП, в \% & Год & Темп роста ВВП, в \% \\
\hline 2013 & 3,5 & 2017 & $-0,7$ \\
\hline 2014 & 2,9 & 2018 & 0,7 \\
\hline 2015 & 1,6 & 2019 & 1,8 \\
\hline 2016 & 0,4 & 2020 & 2,2 \\
\hline Среднее за 2013-2016 & 1,9 & Среднее за 2017-2020 & 0,9 \\
\hline
\end{tabular}

Составлено автором на основе статистических данных официального сайта Министерства финансов Российской Федерации. Информационно-аналитический раздел.http://info.minfin.ru

матическое повышение монетарной стабильности и усиленный контроль денежно-кредитных операций.

Воздействие монетарной политики на выпуск возможно только в краткосрочном периоде. В долгосрочном периоде стимулирующая монетарная политика (увеличение предложения денег) ведет только к росту уровня цен (инфляции), а выпуск остается неизменным - деньги нейтральны. Этот вывод объясняет точку зрения экономистов на неэффективность монетарной политики и следует из уравнения количественной теории денег (см. форм. 1):

$$
M \times V=P \times Y,
$$

где М - количество денег в обращении;

$\mathrm{V}$ - скорость обращения денег, под которой понимается количество оборотов, которое делает в среднем за год одна денежная единица;

$\mathrm{P}$ - общий уровень цен (дефлятор ВВП);

$\mathrm{Y}$ - реальный ВВП.

Если предположить, что скорость обращения денег не меняется и выпуск находится на своем потенциальном уровне $\left(Y=Y^{*}\right)$, то увеличение предложения денег приведет к пропорциональному росту уровня цен, не оказывая влияния на выпуск.

Денежно-кредитная политика страны относится к мерам, принимаемым центральным банком, иногда с участием правительства, для исправления денежно-кредитных и финансовых условий, необходимых для экономической деятельности. Денежно-кредитная политика и налогово-бюджетная политика вместе составляют основу инструментов монетарного регулирования, с целью корректировки макроэкономической среды. Но при наличии определенных условий необходимо принимать во внимание требования, в каковых реализуется любая определенная форма - стагнацию экономики, учено- промышленное развитие, присутствие независимых производственных мощностей, товарных резервов и т.д. В отсутствии учета подобных характеристик концепция монетаризма утрачивает свое практическое значение и преобразуется в тренировочную форму, существующую для поддержания макроэкономических основ. Несмотря на то, теория монетаризма применяется в макроэкономических модификациях агентов иных течений финансовых идей.

Современный финансовый период отличается наличием новых идей, новейших раскладов к оценке сущности действий денежно-кредитных механизмов. Осуществляется формирование и разработка иных принципов монетарной политики, в базу которым ставятся прагматизм и контроль за соблюдением законов монетарного регулирования на практике. По показателям, опубликованным Агентством прогнозирования экономики, в будущем ожидается кризис мировой валютно-финансовой системы, что приведёт к мировому дисбалансу. В периоды сильного экономического роста требования к капиталу для финансовых учреждений должны быть усилены для создания более высоких запасов капитала (антициклических буферов), чтобы их можно было снизить до приемлемого уровня в случае финансового стресса. Этот антициклический буфер капитала сделает финансовую отрасль более устойчивой к потрясениям и поможет снизить внутреннюю процикличность финансовой системы и экономики в целом. Важные уроки, извлеченные из недавнего финансового кризиса в странах с формирующимся рынком, включают необходимость перехода к более гибкому обменному курсу и политике целевых показателей инфляции в России за последние 25 лет. В условиях быстрой финансовой либерализации, денежно-кредитная политика до сих пор была неэффективной в борьбе с инфляцией и адаптации к внешним шокам. В целом, стра- 
ны с формирующейся рыночной экономикой по-прежнему очень уязвимы перед высокой волатильностью притока капитала, и политика по сдерживанию повышения обменного курса вскоре приведет к внутренней инфляции. Важно понимать, что текущие задачи национальной денежно-кредитной политики не могут быть решены по каким-то единым критериям (по курсу, по инфляции и т.д.), как это было в России в 1990-2000 гг. Решение этих проблем требует использования системы контролируемого курса, который учитывает основные факторы формирования денежных потоков и может регулировать диапазон возникающих положительных и отрицательных изменений. Концепция монетаризма, в свою очередь, направлена на избежание последующего обострения финансового упадка и повышения безработицы. Национальная экономика может включать в себя сразу несколько элементов, влияние которых на обстановку экономики способно быть неожиданным. Например, координация между повышением потребительского спроса и эффективностью работы предприятий очевидна, зато зависимость спроса от объема инвестиций более сложна. Атмосфера, сформировавшаяся в данный промежуток в российском экономическом сегменте, показывает необходимость более масштабного использования монетарного подхода в ведении финансовой деятельности, а также в главных отраслях отечественных компаний. Данная теория управления концентрируется в современных теоретических идеях, ее целью является достижение максимальной экономической производительности. Также, устойчивое повышение конкурентоспособности российской экономики произойдёт при наличии эффективной инвестиционно-инновационной деятельности страны. Исследование принципов монетарной школы дает возможность проследить сложные взаимосвязи отдельных структур в экономических системах. Сравнение существующих общепризнанных национальных методов монетарного регулирования с тенденциями развития экономики позволяет нам выявить направления дальнейшего изучения монетарной политики, как основы регулирования экономики России.

\section{Библиографический список}

1. Фетисов Г.Г. Монетарная политика и развитие денежно-кредитной системы России в условиях глобализации: национальный и региональные аспекты - М.: ЗАО «Издательство Экономика», 2008-509с.

2. Балацкий Е. В. Индекс монетарной эффективности и его приложения / Е. В. Балацкий и Н.А. Екимова.- М.: «Перо», 2017-197с.

3. Балацкий Е.В. Краткосрочное прогнозирование с использованием индекса монетарной эффективности// Проблемы прогнозирования / Е. В. Балацкий, Н. А. Екимова.-№ 4, 2018-128с.

4. Закирова Д. Ф. Оценка влияния экономических санкций на банковскую систему Российской Федерации // Актуальные проблемы экономики иправа / Д. Ф. Закирова, Э. Ф. Закирова.-№ 1, 2018-350с.

5. Койбаева М.X. Финансовое регулирование экономики в современных условиях // Азимут научных исследований: экономика и управление. -№ 4, 2014-138с.

6. Ильина Т.Г. Теоретико-методологические основы создания мегарегулятора финансового рынка в России // Проблемы учета и финансов. -№ 2, 2013-200с. 